Article

\title{
Two Novel Cycloartane-Type Triterpenes from Trichilia casaretti C. DC. (Meliaceae)
}

\author{
Ivo Jose Curcino Vieira ${ }^{1, *}$, Elaine Rodrigues Figueiredo ${ }^{2}$, Milena Gonçalves Curcino Vieira ${ }^{3}$, \\ Almir Ribeiro de Carvalho Junior ${ }^{1}$ (D), Michel de Souza Passos ${ }^{1}$, Samyra Imad da Silva Boeno ${ }^{1}$, \\ Otoniel Aquino Azevedo ${ }^{4}$ and Raimundo Braz-Filho ${ }^{1,5}$ (D) \\ 1 Setor de Química de Produtos Naturais, Universidade Estadual do Norte Fluminense Darcy Ribeiro, \\ Campos dos Goytacazes 28013-602, Rio de Janeiro, Brazil; Almir@uenf.br (A.R.d.C.J.); \\ michel.s.p_35@hotmail.com (M.d.S.P.); smr.imad@gmail.com (S.I.d.S.B.); braz@uenf.br (R.B.-F.) \\ 2 Instituto Federal Fluminense, Campus Bom Jesus do Itabapoana, Avenida Dario Vieira Borges, 235, \\ Parque do Trevo, Bom Jesus do Itabapoana 28360-000, Rio de Janeiro, Brazil; elaine.figueiredo@iff.edu.br \\ 3 Faculdade de Medicina de Campos, Avenida Alberto Torres, 217, Centro Campos dos Goytacazes 28035-581, \\ Rio de Janeiro, Brazil; milena.uff@gmail.com \\ 4 Centro Universitário São Camilo, Campus I, Rua São Camilo de Léllis 01, Cachoeiro de Itapemirim \\ 29304-910, Espirito Santo, Brazil; otoazevedo@gmail.com \\ 5 Departamento de Química, Universidade Federal Rural do Rio de Janeiro, CP 74541, Seropédica 23890-000, \\ Rio de Janeiro, Brazil \\ * Correspondence: curcino@uenf.br; Tel.: +55-22-27486504
}

Academic Editor: Vassilios Roussis

Received: 16 March 2018; Accepted: 17 April 2018; Published: 19 April 2018

\begin{abstract}
Two new triterpenes cycloartane-type, named 24-methylencycloartan-12-oxo-3 $\beta, 22 \alpha$-diol and trichiliol, were isolated from the leaves of Trichilia casaretti C. DC. together with three known triterpenes-24-methylencycloart-3 $\beta, 22$-diol, 22,25-dihydrocycloart-23(E)-en-3 $\beta$-ol, and 22(R)-hydroxycycloart-24-en-3-ol. These compounds were characterized on the basis of their spectral data, mainly 1D $\left({ }^{1} \mathrm{H}\right.$ and $\left.{ }^{13} \mathrm{C}\right)$ and 2D NMR $\left({ }^{1} \mathrm{H}-{ }^{1} \mathrm{H}-\mathrm{COSY},{ }^{1} \mathrm{H}-{ }^{1} \mathrm{H}-\mathrm{NOESY}, \mathrm{HMQC}, \mathrm{HSQC}\right.$, and $\mathrm{HMBC}$ ), and mass spectra (EI-MS and HR-ESI-MS), also involving comparison with data from the literature.
\end{abstract}

Keywords: Trichilia casaretti; Meliaceae; triterpenes; cycloartane-type

\section{Introduction}

The Meliaceae family has attracted such a great interest among phytochemists because of its relatively complex and diverse chemical structures and its biological activity, mainly against insects [1-4]. The Trichilia genus (Meliaceae) comprises about 230 species distributed throughout tropical America, which are recognized for their significant economic importance and high commercial value. Phytochemical studies revealed that this genus is a potential source of terpenoids, including triterpenes, limonoids, steroids and other terpenes derivatives [3-6]. Species of this genus have been also studied for their insecticidal activities and their isolated compounds revealed complex and interesting structures including various limonoids $[5,7,8]$. The isolation and structural elucidation of two novel sesquiterpenes from the stems of T. casaretti collected in Espírito Santo State, Brazil, were reported by Vieira et al. in 2010 [4].

In the present article, we describe an investigation of methanol extract from leaves of a $T$. casaretti specimen, which allowed the characterization of five triterpenes, including two novel cycloartane-type triterpenes named 24-methylencycloartane-12-oxo-3 $\beta, 22 \alpha$-diol (1) and

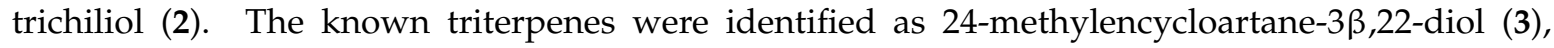


cycloartane-22(E)-en-3 3,22,25-triol (4), and 22(R)-hydroxycycloart-24-en-3-ol (5). Their structures (Figure 1) were established by spectrometric techniques, mainly 1D and 2D NMR, and HR-ESI-MS, and comparison with literature data.

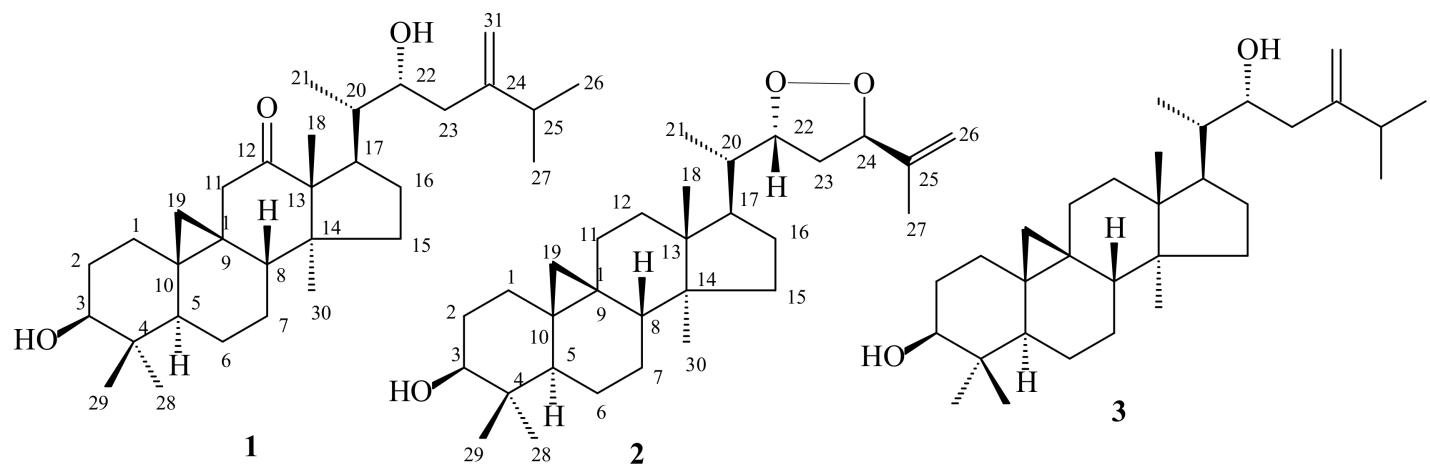

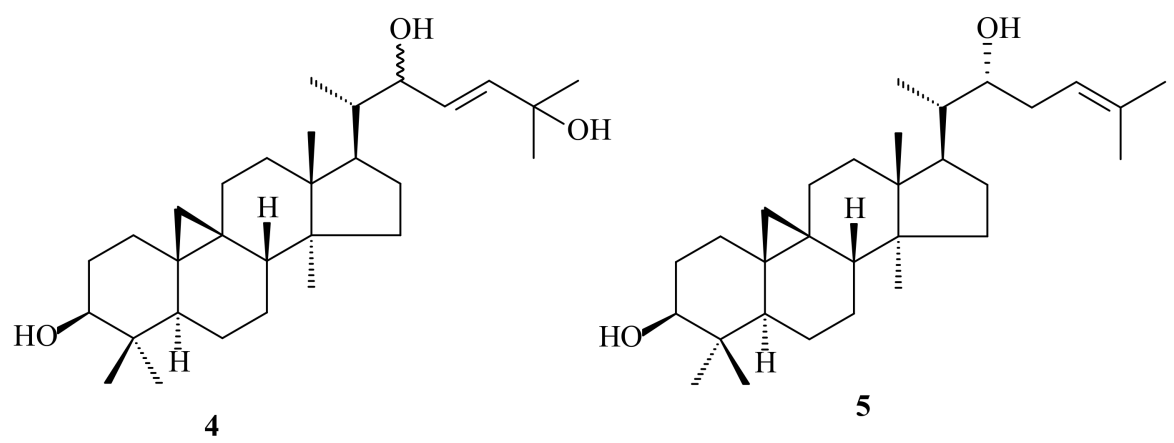

Figure 1. Triterpenes isolated from Trichilia casaretti.

\section{Results and Discussion}

Fractionation of the $\mathrm{MeOH}$ extract of the leaves from $T$. casaretti by classical chromatographic methods resulted in the isolation of five cycloartane-type triterpenes 1-5 whose structures are shown in Figure 1. The two novel cycloartane-type triterpenes named 24-methylencycloartan-12-oxo-3 $\beta, 22 \alpha$-diol (1) and trichiliol (2), along with three known triterpenes,

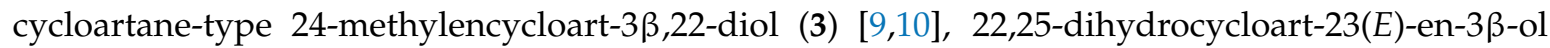
(4) $[9,11]$ and 22(R)-hydroxycycloart-24-en-3-ol (5) [12] were characterized on the basis of ${ }^{1} \mathrm{H}$ and ${ }^{13} \mathrm{C}$-NMR spectral data, especially 2D NMR and mass spectral data, besides comparison with values described in the cited literature.

The new triterpene named 24-methylencycloartan-12-oxo-3 $\beta, 22 \alpha$-diol(1) was isolated as yellow oil, $[\alpha]_{\mathrm{D}}^{23}=+27.3\left(\mathrm{CHCl}_{3}, c 0.02\right)$. The analysis of the $\left\{{ }^{1} \mathrm{H}\right\}$ - and ${ }^{13} \mathrm{C}$-APT NMR spectra (Table 1$)$ revealed signals corresponding to $31 \mathrm{C}$-atoms, including seven quaternary $\mathrm{C}$ (five $\mathrm{sp}^{3}$ and two $\mathrm{sp}^{2}$, one attributed to methylidene at $\delta_{\mathrm{C}} 153.5(\mathrm{C}-24)$ and one $\mathrm{C}=\mathrm{O}$ group at $\delta_{\mathrm{C}} 216.0(\mathrm{C}-12)$ ), seven $\mathrm{CH}$ (all sp ${ }^{3}$, including two linked to $O$ atom at $\delta_{\mathrm{C}} 78.8(\mathrm{CH}-3)$ and $70.3(\mathrm{CH}-22)$, nine methylene $\mathrm{CH}_{2}$ (including one sp ${ }^{2}$ at $\left.\delta_{\mathrm{C}} 109.8\left(\mathrm{CH}_{2}-31\right)\right)$ and seven methyl groups $\mathrm{CH}_{3}$, allowing to deduce the expanded partial formula $\mathrm{C}_{6}(\mathrm{C}=\mathrm{O}) \mathrm{CH}_{5}(\mathrm{OCH})_{2}\left(\mathrm{CH}_{2}\right)_{10}\left(\mathrm{CH}_{3}\right)_{7}=\mathrm{C}_{31} \mathrm{H}_{48} \mathrm{O}_{3}$ or $\mathrm{C}_{6}(\mathrm{C}=\mathrm{O}) \mathrm{CH}_{5}(\mathrm{HOCH})_{2}\left(\mathrm{CH}_{2}\right)_{10}\left(\mathrm{CH}_{3}\right)_{7}=\mathrm{C}_{31} \mathrm{H}_{50} \mathrm{O}_{3}$ based in the presence of two hydroxyl groups. 
Table $1 .{ }^{13} \mathrm{C}$ and ${ }^{1} \mathrm{H}-\mathrm{NMR}$ data of triterpene 1 and comparison with triterpene $3\left(\mathrm{CDCl}_{3}\right), \delta$ in ppm, coupling constants $(\mathrm{J}$ in $\mathrm{Hz}$, in parenthesis) *.

\begin{tabular}{|c|c|c|c|c|c|}
\hline \multirow[t]{3}{*}{$\mathrm{C}$} & \multicolumn{4}{|c|}{1} & \multirow[t]{2}{*}{3} \\
\hline & & HMQC $(\mathrm{H} \rightarrow \mathrm{C})$ & & $\mathrm{IBC}(\mathrm{C} \rightarrow \mathrm{H})$ & \\
\hline & $\delta(C)$ & $\delta(\mathrm{H})$ & ${ }^{2} J$ & ${ }^{3} J$ & $\delta(C)$ \\
\hline 1 & 32.8 & $1.65-1.55(m, 2 \mathrm{H})$ & & $2 \mathrm{H}-19$ & 32.0 \\
\hline 2 & 32.0 & $\begin{array}{l}1.78-1.80(m, 1 \mathrm{H}) \\
1.62-1.55(m, 1 \mathrm{H})\end{array}$ & & & 30.4 \\
\hline 3 & 78.8 & $3.28(d d, 11.1 ; 4.1,1 \mathrm{H})$ & & $3 \mathrm{H}-28,3 \mathrm{H}-29$ & 78.8 \\
\hline 4 & 40.7 & - & $3 \mathrm{H}-28,3 \mathrm{H}-29$ & & 40.8 \\
\hline 5 & 48.0 & $1.30-1.25(m, 2 \mathrm{H})$ & & $3 \mathrm{H}-28,3 \mathrm{H}-29$ & 47.1 \\
\hline 6 & 21.6 & $\begin{array}{l}1.58-1.62(m, 1 \mathrm{H}) \\
0.78-0.80(m, 1 \mathrm{H})\end{array}$ & & & 21.1 \\
\hline 7 & 25.4 & $\begin{array}{l}1.28-1.30(m, 1 \mathrm{H}) \\
1.10-1.16(m, 1 \mathrm{H})\end{array}$ & & & 27.2 \\
\hline 8 & 47.1 & $1.30(b r s, 1 \mathrm{H})$ & & $3 \mathrm{H}-30$ & 48.0 \\
\hline 9 & 19.5 & - & & & 20.0 \\
\hline 10 & 29.9 & - & & & 26.1 \\
\hline 11 & 27.2 & n.d. & & $2 \mathrm{H}-19$ & 26.1 \\
\hline 12 & 218.0 & - & & $3 \mathrm{H}-18$ & 35.7 \\
\hline 13 & 49.0 & - & $3 \mathrm{H}-18$ & $3 \mathrm{H}-30$ & 45.8 \\
\hline 14 & 48.0 & - & $3 \mathrm{H}-30$ & $3 \mathrm{H}-18$ & 48.4 \\
\hline 15 & 45.7 & $1.30-1.34(m, 2 \mathrm{H})$ & & $3 \mathrm{H}-30$ & 32.9 \\
\hline 16 & 25.4 & $\begin{array}{l}2.01-2.05(m, 1 \mathrm{H}) \\
1.30-1.34(m, 1 \mathrm{H})\end{array}$ & & & 26.4 \\
\hline 17 & 49.0 & $1.49-1.53(m, 1 \mathrm{H})$ & & $3 \mathrm{H}-18,3 \mathrm{H}-21$ & 49.0 \\
\hline 18 & 12.1 & $0.91(s, 3 \mathrm{H})$ & & $\mathrm{H}-12, \mathrm{H}-17$ & 18.0 \\
\hline 19 & 30.3 & $\begin{array}{l}0.56(d, 4.1,1 \mathrm{H}) \\
0.35(d, 4.1,1 \mathrm{H})\end{array}$ & & $2 \mathrm{H}-1$ & 29.9 \\
\hline 20 & 40.9 & $1.88-1.80(m, 1 \mathrm{H})$ & $3 \mathrm{H}-21$ & & 40.5 \\
\hline 21 & 19.5 & $0.90(d, 5.8,3 \mathrm{H})$ & $\mathrm{H}-20$ & $\mathrm{H}-17, \mathrm{H}-22$ & 12.0 \\
\hline 22 & 70.3 & $3.78(b r d, 10.6,1 \mathrm{H})$ & & & 70.4 \\
\hline 23 & 36.1 & $\begin{array}{c}2.24(d, 13.5,1 \mathrm{H}) \\
1.95(d d, 13.5 ; 11.2,1 \mathrm{H})\end{array}$ & $\mathrm{H}-22$ & $2 \mathrm{H}-31$ & 36.1 \\
\hline 24 & 153.5 & - & $2 \mathrm{H}-23,2 \mathrm{H}-31$ & $3 \mathrm{H}-26,3 \mathrm{H}-27$ & 153.6 \\
\hline 25 & 33.1 & $2.20-2.24(m, 1 \mathrm{H})$ & & & 33.2 \\
\hline 26 & 22.3 & $1.05(d, 7.0,3 \mathrm{H})$ & & & 22.3 \\
\hline 27 & 21.6 & $1.08(d, 7.0,3 \mathrm{H})$ & & & 21.6 \\
\hline 28 & 25.4 & $0.97(s, 3 \mathrm{H})$ & & H-3, H-5, 3H-29 & $19.5^{\mathrm{a}}$ \\
\hline 29 & 14.2 & $0.81(s, 3 \mathrm{H})$ & & H-3, H-5, 3H-28 & 14.0 \\
\hline 30 & 18.0 & $1.01(s, 3 \mathrm{H})$ & & $\mathrm{H}-8,2 \mathrm{H}-15$ & $25.4^{\mathrm{a}}$ \\
\hline 31 & 109.8 & $4.93(s, 1 \mathrm{H}) / 4.84(s, 1 \mathrm{H})$ & & $2 \mathrm{H}-23$ & 109.7 \\
\hline
\end{tabular}

\footnotetext{
* Number of hydrogens bound to carbon atoms deduced by comparative analysis of $\left\{{ }^{1} \mathrm{H}\right\}$ - and APT- ${ }^{13} \mathrm{C}-\mathrm{NMR}$ spectra. Chemical shifts and coupling constants $(J)$ obtained of $1 \mathrm{D}^{1} \mathrm{H}-\mathrm{NMR}$ spectrum. Superimposed ${ }^{1} \mathrm{H}$ signals are described without multiplicity and approximated chemical shifts deduced by HMQC, $\mathrm{HMBC}$ and ${ }^{1} \mathrm{H}-{ }^{1} \mathrm{H}-\mathrm{COSY}$ spectra. Assignments determined by a combination of $1 \mathrm{D}$ and $2 \mathrm{D}\left({ }^{1} \mathrm{H}^{-}{ }^{1} \mathrm{H}-\mathrm{COSY}, \mathrm{HSQC}\right.$ and HMBC) NMR experiments. ${ }^{a}$ Chemical shifts with same letter cam be exchanged. n.d. $=$ not detected.
}

The HR-ESI-MS spectrum of 1 showed peak corresponding to the quasi molecular ion $\left([\mathrm{M}+\mathrm{H}]^{+}\right)$ at $m / z$ 471.3475, that in combination with ${ }^{1} \mathrm{H}-\mathrm{NMR}$ (1D and 2D) and comparative analysis of the $\left\{{ }^{1} \mathrm{H}\right\}$ - and ${ }^{13} \mathrm{C}$-APT NMR spectra (Table 1) enabled us to propose the molecular formula $\mathrm{C}_{31} \mathrm{H}_{50} \mathrm{O}_{3}$ (seven degrees of unsaturation) compatible with a cycloartane-type 24-methylencycloart-3 $\beta, 22$-diol (3) skeleton [9]. The only difference regarding compounds $\mathbf{1}$ and $\mathbf{3}$ consists of a carbonyl group at C-12.

The signal at $\delta_{C} 216.0$ in the ${ }^{13} \mathrm{C}$-APT NMR spectrum suggested the presence of a carbonyl group in the triterpene cycloartane 1 . The location of the carbonyl group at $\mathrm{C}-12$ was supported in the HMBC spectrum by the correlation $\left({ }^{3} J_{\mathrm{HC}}\right)$ between $\mathrm{C}-12\left(\delta_{\mathrm{C}} 216.0\right)$ and the hydrogens of the 
methyl group $3 \mathrm{H}-18$ at $\delta_{\mathrm{H}} 0.90$. Thus, the new triterpene cycloartane-type was characterized as 24-methylidencycloartan-12-oxo-3 $\beta, 22$-diol (1).

Compound 2 was isolated as a yellow oil, $[\alpha]_{\mathrm{D}}^{23}=+48.0\left(\mathrm{CHCl}_{3}, c 0.001\right)$. The analysis of the $\left\{{ }^{1} \mathrm{H}\right\}-$ and ${ }^{13} \mathrm{C}$-NMR spectra (Table 2) revealed signals corresponding to 30 carbon atoms, showing similarity with the triterpene cycloartane $\mathbf{1}$. Comparison of the ${ }^{13} \mathrm{C}-\mathrm{NMR}$ data of compounds $\mathbf{1}$ and $\mathbf{2}$ revealed the absence of carbonyl signal in $\mathbf{2}$, and additional differences can be justified through modifications involving only the side chain (Tables 1 and 2).

The ${ }^{13} \mathrm{C}$-NMR spectrum of 2 with the presence of 30 carbon signals revealed additional carbon signals corresponding to remaining carbon atoms $(\mathrm{C})(\mathrm{CH})(\mathrm{OCH})_{2}\left(\mathrm{CH}_{2}\right)_{2}\left(\mathrm{CH}_{3}\right)_{2}=\mathrm{C}_{8} \mathrm{H}_{13} \mathrm{O}_{2}$ of the side chain, different of the cycloartane triterpene 1 with signals representing 31 carbon atoms including $(\mathrm{C})(\mathrm{CH})_{2}(\mathrm{HOCH})\left(\mathrm{CH}_{2}\right)_{2}\left(\mathrm{CH}_{3}\right)_{3}=\mathrm{C}_{9} \mathrm{H}_{17} \mathrm{O}$ of the side chain.

The ${ }^{13} \mathrm{C}$-NMR spectrum involving the side chain of 2 revealed signals representing only two methyl groups when compared with those of 1 with three, one corresponding to $\mathrm{CH}_{3}-21$ at $\delta_{\mathrm{C}} 19.5$ correlated in the HSQC with the doublet $(J=6.3 \mathrm{~Hz})$ signal at $\delta_{\mathrm{H}} 1.22(3 \mathrm{H}-21)$ and one attached to $\mathrm{sp}^{2}$ carbon $\left(\mathrm{CH}_{3}-27, \delta_{\mathrm{H}} 2.01 \backslash \delta_{\mathrm{C}} 18.5\right)$, two sp ${ }^{2}$ carbon atoms at $\delta_{\mathrm{C}} 147.8(\mathrm{C}-25)$ and $112.5\left(\mathrm{CH}_{2}-26\right)$, featuring a methylidene group $=\mathrm{CH}_{2}$ confirmed by correlations $\left({ }^{1} J_{\mathrm{HC}}\right)$ between $\delta_{\mathrm{C}} 112.48\left(\mathrm{CH}_{2}-26\right)$ with two broad singlets at $\delta_{\mathrm{H}} 5.32(\mathrm{Ha}-26)$ and $5.10(\mathrm{Hb}-26)$ observed in the HSQC spectrum.

The location of the methylidene group at the $\mathrm{C}-25$ was confirmed through the ${ }^{2} J_{\mathrm{HC}}$ correlations between $\mathrm{C}-25\left(\delta_{\mathrm{C}} 147.8\right)$ and $3 \mathrm{H}-27\left(\delta_{\mathrm{H}} 2.01\right)$ and $\mathrm{C}-26\left(\delta_{\mathrm{C}} 112.5\right)$ with $3 \mathrm{H}-27\left(\delta_{\mathrm{H}} 2.01\right)$. The presence of a isopropenyl group (isopropyl in 1$)$ attached to $\mathrm{CH}-24\left(\delta_{\mathrm{C}} 86.6 \backslash \delta_{\mathrm{H}} 5.32, b r \mathrm{~s}\right)$ was deduced by HSQC and $\mathrm{HMBC}$ correlations between $\mathrm{CH}-24$ and $3 \mathrm{H}-27\left[\left(\delta_{\mathrm{H}} 2.01, b r s \backslash\left(\delta_{\mathrm{C}} 18.5,{ }^{3} J_{\mathrm{HC}}\right)\right]\right.$. It was also possible to observe the interaction between $\mathrm{CH}-22\left(\delta_{\mathrm{C}} 69.87 .6 \backslash\left(\delta_{\mathrm{H}} 4.55, b r d, J=10.0 \mathrm{~Hz}\right)\right.$ and $3 \mathrm{H}-21\left(\delta_{\mathrm{H}} 1.22\right.$, $d, J=6.3 \mathrm{~Hz} \backslash\left(\delta_{\mathrm{C}} 12.8,{ }^{3} J_{\mathrm{HC}}\right)$. These data allowed to postulate the presence of oxygen atoms linked to carbon 22 (HC-O-22: $\left.\delta_{\mathrm{H}} 4.55 \backslash 69.7\right)$ and 24 (HC-O-24 $\left.\delta_{\mathrm{H}} 5.32 \backslash 86.6\right)$, in agreement with the ${ }^{1} \mathrm{H}-{ }^{1} \mathrm{H}-\mathrm{COSY}$ spectrum which showed correlations between the methylene hydrogens $2 \mathrm{H}-23\left(\delta_{\mathrm{H}} 2.10\right.$ and $1.90 \backslash \delta_{\mathrm{C}}$ 34.5) and both hydrogen atoms $\mathrm{H}-22\left(\delta_{\mathrm{H}} 4.55\right)$ and $\mathrm{H}-24$ at $\delta_{\mathrm{H}} 5.32$ (chemical shift justified by location in position allylic and carbinolic). Other heteronuclear correlations observed in the HMBC spectrum of 2 were shown in Table 2.

The endoperoxide function in the side chain was also supported by mass spectra of low and high resolution demanding an additional ring to suit the seven degrees of unsaturation. The HRESI-MS spectrum of 2 (Scheme S1, Supplementary Materials) showed peak corresponding to the protonated molecular ion $[\mathrm{M}+\mathrm{H}]^{+}$at $m / z 457.3502$ which together with the NMR spectrum of ${ }^{13} \mathrm{C}$-DEPT $135^{\circ}$ NMR allowed to propose the molecular formula $\mathrm{C}_{30} \mathrm{H}_{48} \mathrm{O}_{3}$ compatible with a cycloartane-type skeleton and one heterocyclic involving the peroxide function.

The relative stereochemistry indicated in $\mathbf{2}$ was deduced by the spatial dipolar interaction observed in the ${ }^{1} \mathrm{H}-{ }^{1} \mathrm{H}-\mathrm{NOESY}$ spectrum between $3 \mathrm{H}-30$ and $\mathrm{H}-17$ indicating $\mathrm{H}-17 \alpha$, interaction of $3 \mathrm{H}-18$ with $\mathrm{H}-20$ and $3 \mathrm{H}-21$ with $\mathrm{H}-12$ equatorial suggesting $\mathrm{H}-20 \alpha$ and $\mathrm{CH}_{3}-21 \alpha$, respectively. Other spatial dipolar interaction was shown in Figure 2. These data allowed to identify compound 2 as the new triterpene 22,24-peroxidecycloart-25-en-3 $\beta$-ol (2), named trichiliol. 
Table 2. ${ }^{13} \mathrm{C}$ - and ${ }^{1} \mathrm{H}-\mathrm{NMR}$ data of triterpene 2 (pyridine- $\left.d_{5}\right), \delta$ in ppm, coupling constants $(\mathrm{J}$ in $\mathrm{Hz}$, in parenthesis) *.

\begin{tabular}{|c|c|c|c|c|}
\hline \multirow[t]{3}{*}{$\mathrm{C}$} & \multicolumn{4}{|c|}{2} \\
\hline & \multicolumn{2}{|r|}{$\mathrm{HSQC}(\mathrm{H} \rightarrow \mathrm{C})$} & \multicolumn{2}{|c|}{$\operatorname{HMBC}(\mathrm{C} \rightarrow \mathrm{H})$} \\
\hline & $\delta(\mathrm{C})$ & $\delta(\mathrm{H})$ & ${ }^{2} J$ & ${ }^{3} \mathrm{~J}$ \\
\hline 1 & 32.8 & $\begin{array}{l}1.50-1.53(m, 1 \mathrm{H}) \\
1.25-1.26(m, 1 \mathrm{H})\end{array}$ & & 2H (19) \\
\hline 2 & 31.6 & $\begin{array}{l}2.00-2.01(m, 1 \mathrm{H}) \\
1.94-1.98(m, 1 \mathrm{H})\end{array}$ & & \\
\hline 3 & 78.3 & $3.57(b r d, 9.0,1 \mathrm{H})$ & & $3 \mathrm{H}-28,3 \mathrm{H}-29$ \\
\hline 4 & 41.5 & - & $3 \mathrm{H}-28,3 \mathrm{H}-29$ & \\
\hline 5 & 47.9 & $1.33(m, 1 \mathrm{H})$ & $2 \mathrm{H}-6$ & $3 \mathrm{H}-28,3 \mathrm{H}-29$ \\
\hline 6 & 21.8 & $\begin{array}{l}1.60-1.65(m, 1 \mathrm{H}) \\
0.77-0.82(m, 1 \mathrm{H})\end{array}$ & $\mathrm{H}-5$ & \\
\hline 7 & 26.8 & $1.12-1.05(m, 2 \mathrm{H})$ & $\mathrm{H}-8$ & \\
\hline 8 & 48.6 & $1.46-1.50(m, 1 \mathrm{H})$ & $2 \mathrm{H}-7$ & $3 \mathrm{H}-30$ \\
\hline 9 & 20.3 & - & $2 \mathrm{H}-19$ & \\
\hline 10 & 26.9 & - & $\mathrm{H}-5,2 \mathrm{H}-19$ & \\
\hline 11 & 27.0 & $\begin{array}{l}2.00-2.10(m, 1 \mathrm{H}) \\
1.25-1.30(m, 1 \mathrm{H})\end{array}$ & & $2 \mathrm{H}-19$ \\
\hline 12 & 33.4 & $1.60-1.72(m, 2 \mathrm{H})$ & & $3 \mathrm{H}-18$ \\
\hline 13 & 46.2 & - & $3 \mathrm{H}-18-$ & $3 \mathrm{H}-30$ \\
\hline 14 & 48.9 & - & $3 \mathrm{H}-30$ & $3 \mathrm{H}-18$ \\
\hline 15 & 36.3 & $\begin{array}{l}2.10-2.20(m, 1 \mathrm{H}) \\
1.20-1.30(m, 1 \mathrm{H})\end{array}$ & & $3 \mathrm{H}-30$ \\
\hline 16 & 28.0 & $\begin{array}{l}2.22-2.38(m, 1 \mathrm{H}) \\
1.90-2.00(m, 1 \mathrm{H})\end{array}$ & & \\
\hline 17 & 49.9 & $1.80(b r q, 9.0,1 \mathrm{H})$ & & $3 \mathrm{H}-18,3 \mathrm{H}-21$ \\
\hline 18 & 18.7 & $1.03(s, 3 \mathrm{H})$ & & H-17 \\
\hline 19 & 30.5 & $\begin{array}{l}0.54(b r s, 1 \mathrm{H}) \\
0.33(b r s, 1 \mathrm{H})\end{array}$ & & $2 \mathrm{H}-1,2 \mathrm{H}-11$ \\
\hline 20 & 43,6 & $2.05-2.25(\mathrm{~m})$ & $3 \mathrm{H}-21-$ & \\
\hline 21 & 12.8 & $1.22(d, 6.3,3 \mathrm{H})$ & $\mathrm{H}-20$ & $\mathrm{H}-17, \mathrm{H}-22$ \\
\hline 22 & 69.7 & $4.55(b r d, 10.0,1 \mathrm{H})$ & & $3 \mathrm{H}-21$ \\
\hline 23 & 34.5 & $\begin{array}{l}2.20-2.30(m, 1 \mathrm{H}) \\
1.85-1.90(m, 1 \mathrm{H})\end{array}$ & & \\
\hline 24 & 86.6 & $5.32(b r s, 1 \mathrm{H})$ & & $3 \mathrm{H}-27$ \\
\hline 25 & 147.8 & - & $3 \mathrm{H}-27$ & \\
\hline 26 & 112.5 & $\begin{array}{l}5.32(b r s, 1 \mathrm{H}) \\
5.10(b r s, 1 \mathrm{H})\end{array}$ & & $3 \mathrm{H}-27$ \\
\hline 27 & 18.5 & $2.01(b r s, 3 \mathrm{H})$ & $\mathrm{H}-25$ & $\mathrm{H}-24,2 \mathrm{H}-26$ \\
\hline 28 & 26.6 & $1.25(s, 3 \mathrm{H})$ & & $\mathrm{H}-3, \mathrm{H}-5,3 \mathrm{H}-29$ \\
\hline 29 & 15.2 & $1.22(s, 3 \mathrm{H})$ & & H-3, H-5, 3H-28 \\
\hline 30 & 20.1 & $0.89(s, 3 \mathrm{H})$ & & $\mathrm{H}-8,2 \mathrm{H}-15$ \\
\hline
\end{tabular}

* Number of hydrogens bounded to carbon atoms deduced by comparative analysis of $\left\{{ }^{1} \mathrm{H}\right\}$ - and APT -13 C-NMR spectra. Chemical shifts and coupling constants $(J)$ obtained of $1 \mathrm{D}^{1} \mathrm{H}-\mathrm{NMR}$ spectrum. Superimposed ${ }^{1} \mathrm{H}$ signals are described without multiplicity and approximated chemical shifts deduced by HSQC, HMBC and ${ }^{1} \mathrm{H}-{ }^{1} \mathrm{H}-\mathrm{COSY}$ spectra. Assignments deduced by a combination of $1 \mathrm{D}$ and $2 \mathrm{D}\left({ }^{1} \mathrm{H}-{ }^{1} \mathrm{H}-\mathrm{COSY}, \mathrm{HSQC}\right.$ and HMBC) NMR experiments. 


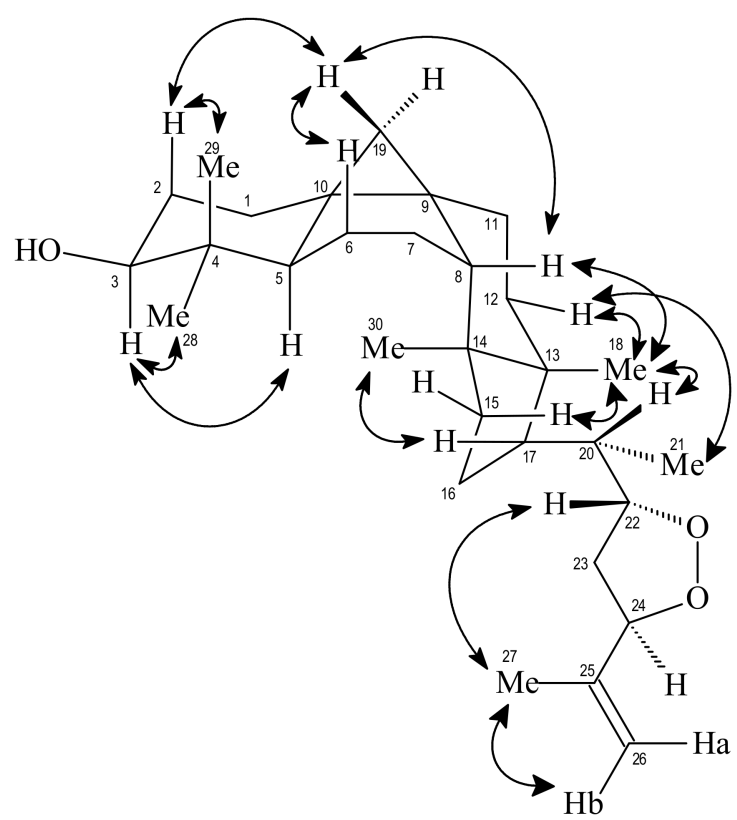

Figure 2. Selected Nuclear Overhauser Effect (NOE) correlations and relative stereochemistry for compound 2. Arrows denote the main NOE correlations.

\section{Material and Methods}

\subsection{General Methods}

Measures of optic rotation were obtained on a Perkin Elmer 343 digital polarimeter. Melting point was obtained on a Microquímica MQRPF. EI-MS (low resolution) mass spectra were obtained on Shimadzu QP5050A mass spectrometer. HRESI-MS (high resolution) mass spectra were obtained by using a ESI-IT-OF-MS SHIMADZU mass spectrometer, using the positive ion mode of analysis. Chromatographic purifications were carried out over silica gel 60 (70-230 mesh). Silica gel $60 \mathrm{~F}_{254}$ was used in thin layer chromatography analysis. ${ }^{1} \mathrm{H}$ and ${ }^{13} \mathrm{C}-\mathrm{NMR}$ spectra were measured on a Bruker model DRX-500 and Jeol model Eclipse-400 spectrometers, equipped with inverse probes and field gradient, operating at $500\left({ }^{1} \mathrm{H}\right)$ and $125\left({ }^{13} \mathrm{C}\right)$ and $400\left({ }^{1} \mathrm{H}\right)$ and $100\left({ }^{13} \mathrm{C}\right) \mathrm{MHz} . \mathrm{CDCl}_{3}$ and pyridine- $d_{5}$ were used as solvents and TMS as internal reference. Chemical shifts are given in the $\delta$ scale (ppm) and coupling constants $J$ in $\mathrm{Hz}$. One dimensional (1D) ${ }^{1} \mathrm{H}$ and ${ }^{13} \mathrm{C}-\mathrm{NMR}$ spectra were acquired under standard conditions by using a direct detection $5 \mathrm{~mm}{ }^{1} \mathrm{H} /{ }^{13} \mathrm{C}$ dual probe. Standard pulse sequences were used for two dimensional spectra by using a multinuclear inverse detection $5 \mathrm{~mm}$ probe with field gradient.

\subsection{Plant Material}

The leaves of Trichilia casaretti C. DC. were collected at Vale Cia, Linhares City, Espirito Santo State, Brazil, and identified by Domingos Folly. A voucher specimen (CVRD-449) was deposited at the Vale Cia of Vale herbarium, Vale Cia, Linhares City, Espirito Santo State, Brazil.

\subsection{Extract and Isolation}

Air dried and powdered leaves $(920 \mathrm{~g})$ from Trichilia casaretti C. DC. were extracted with methanol at room temperature, yielding $15.0 \mathrm{~g}$ of crude methanol extract. The methanol extract was submitted to liquid-liquid partition $\left(\mathrm{CH}_{2} \mathrm{Cl}_{2}: \mathrm{H}_{2} \mathrm{O}, 3: 1, v / v\right)$. The $\mathrm{CH}_{2} \mathrm{Cl}_{2}$ fraction $(10.1 \mathrm{~g})$ was submitted to liquid-liquid partition (MeOH:Hexane, 1:1, v/v). The methanol fraction $(8.0 \mathrm{~g})$ was chromatographed over a silica gel column with a gradient of ethyl acetate/hexane, affording eight fractions. Fraction 1 $(19.3 \mathrm{mg})$ was similarly rechromatographed, yielding triterpene $\mathbf{5}(8.0 \mathrm{mg})$. Fraction $5(518 \mathrm{mg})$ was 
analogously rechromatographed, affording eleven fractions. Fraction $5.7(66.8 \mathrm{mg})$ was similarly chromatographed, affording triterpene $4(4.0 \mathrm{mg})$. Fraction $7(6.736 \mathrm{mg})$ was chromatographed affording fifteen fractions. The fraction $7.5(1.300 \mathrm{mg})$ was rechromatographed affording fourteen fractions. The triterpene $2(10 \mathrm{mg})$ was obtained from the fractions 7.5.3 $(45 \mathrm{mg})$ and 7.5.4 $(100 \mathrm{mg})$. The triterpene $1(25 \mathrm{mg})$ was obtained from the fraction $7.6(500 \mathrm{mg})$. The fraction $7.9(163 \mathrm{mg})$ was chromatographed affording fifteen fractions. The fraction 7.9.2 (50.3 mg) yielded triterpene $3(11 \mathrm{mg})$.

Supplementary Materials: Figures S1-S18 and Schemes S1 and S2 are available online.

Acknowledgments: The authors are grateful to Fundação de Amparo à Pesquisa do Estado do Rio de Janeiro (FAPERJ), to Conselho Nacional de Desenvolvimento Científico e Tecnológico (CNPq), and to Coordenação de Aperfeiçoamento de Pessoal de Ensino Superior (CAPES).

Author Contributions: All authors contributed equally to develop this work.

Conflicts of Interest: No potential conflict of interest.

\section{References}

1. Pennington, T.D.; Styles, B.D. A generic monograph of the Meliaceae. Blumea 1975, 22, 419-540.

2. Pupo, M.T.; Adorno, M.A.; Vieira, P.C.; Fernandes, J.B.; Silva, M.F.G.F.; Pirani, J.R. Terpenoids and steroids from Trichilia species. J. Braz. Chem. Soc. 2002, 13, 382-388. [CrossRef]

3. Rodrigues, V.F.; Carmo, H.M.; Braz-Filho, R.; Mathias, L.; Vieira, I.J.C. Two new terpenoids from Trichilia quadrijuga (Meliaceae). Nat. Prod. Comm. 2010, 5, 179-184.

4. Vieira, I.J.C.; Figueiredo, E.R.; Freitas, V.R.; Mathias, L.; Braz-Filho, R.; Araújo, R.M. A new sesquiterpene from Trichilia casaretti (Meliaceae). Am. J. Anal. Chem. 2010, 1, 70-72. [CrossRef]

5. Freitas, V.R.; Carmo, H.M.; Oliveira, R.R.; Braz-Filho, R.; Mathias, L.; Vieira, I.J.C. Isolation of terpenoids from Trichilia quadrijuga (Meliaceae) by droplet counter-current chromatography. Chromatographia 2009, 70, 1191-1195.

6. Ramírez, M.C.; Toscano, R.A.; Arnason, J.; Omar, S.; Cerda-Garcia-Rojas, C.M.; Mata, R. Structure, conformation and absolute configuration of new antifeedant dolabellanes from Trichilia trifolia. Tetrahedron 2000, 56, 5085-5091. [CrossRef]

7. Xie, Y.S.; Isman, M.B.; Gunning, P.; Mackinnon, S.; Arnason, J.T.; Taylor, D.R.; Sánchez, P.; Hasbun, C.; Towers, G.H.N. Biological activity of extracts of Trichilia species and the limonoid hirtin against lepidopteran larvae. Biochem. Syst. Ecol. 1994, 22, 129-136. [CrossRef]

8. Cortez, D.A.G.; Fernandes, J.B.; Vieira, P.C.; Silva, M.F.G.F.; Ferreira, A.G.; Cass, Q.B.; Pirani, J.R. Meliacin butenolides from Trichilia estipulate. Phytochemistry 1998, 49, 2493-2496. [CrossRef]

9. Lago, J.H.G.; Roque, N.F. Cycloartane triterpenoids from Guarea macrophylla. Phytochemistry 2002, 60, 329-332. [CrossRef]

10. Yang, A.; Shang, Q.; Yang, L.; Li, C.; Yuan, H.J. Chemical Constituents of the Flowerbuds of Tussilago farfara. Chem. Nat. Compd. 2017, 53, 584-585. [CrossRef]

11. Khan, M.T.H.; Khan, S.B.; Ather, A. Tyrosinase inhibitory cycloartane type triterpenoids from the methanol extract of the whole plant of Amberboa ramosa Jafri and their structure-activity relationship. Bioorg. Med. Chem. 2006, 14, 938-943. [CrossRef] [PubMed]

12. Bohlmann, F.; Misra, L.N.; Jakupovic, J.; King, R.M.; Robinson, H. Guaianolides, heliangolides, diterpenes and cycloartenol derivatives from Balsamorhiza sagittata. Phytochemistry 1985, 24, 2029-2036. [CrossRef]

Sample Availability: Samples of the compounds are not available from the authors.

(C) 2018 by the authors. Licensee MDPI, Basel, Switzerland. This article is an open access article distributed under the terms and conditions of the Creative Commons Attribution (CC BY) license (http://creativecommons.org/licenses/by/4.0/). 